\title{
Rumen epithelial adaptation to ruminal acidosis in lactating cattle involves the coordinated expression of insulin-like growth factor-binding proteins and a cholesterolgenic enzyme
}

\author{
M. A. Steele, L. Dionissopoulos, O. AlZahal, J. Doelman, and B. W. McBride ${ }^{1}$ \\ Department of Animal and Poultry Science, University of Guelph, Guelph, N1G 2W1, Canada
}

\begin{abstract}
The objective of this study was to characterize the mRNA expression of metabolic and proliferative genes in the rumen epithelium during ruminal acidosis. To meet our objectives, 16 rumen-fistulated, lactating Holstein dairy cattle $(618 \pm 35 \mathrm{~kg}$ of body weight, 221 $\pm 32 \mathrm{~d}$ in milk) were used in a randomized complete block design. All cattle were fed a high-forage diet (HF; $88.9 \%$ of dry matter) for 5 wk before the experiment. After the baseline week (wk 0), half of the cattle were randomly assigned and transitioned to a high-concentrate diet (HC; $62.2 \%$ of dry matter) which was fed for $3 \mathrm{wk}$ (wk 1,2, and 3). For the last $48 \mathrm{~h}$ of each week, continuous ruminal $\mathrm{pH}$, short-chain fatty acids, and plasma $\beta$-hydroxybutyrate were assessed, followed by a rumen papillae biopsy. Milk production was higher in $\mathrm{HC}$ cattle compared with $\mathrm{HF}$ during wk 1,2 , and 3 $(17.4 \pm 0.5$ vs. $23.4 \pm 0.9 \mathrm{~kg} / \mathrm{d}$, respectively); however, the mean ruminal $\mathrm{pH}$ was decreased $(5.75 \pm 0.03$ vs. $6.30 \pm 0.02)$. The $\mathrm{HC}$ cattle spent more time below $\mathrm{pH}$ $5.6(594 \pm 54$ vs. $3 \pm 3 \mathrm{~min} / \mathrm{d})$ and displayed greater concentrations of ruminal butyrate $(15.8 \pm 0.9$ vs. 10.2 $\pm 0.4 \mathrm{mmol})$ and plasma $\beta$-hydroxybutyrate $(1,036 \pm$ 63 vs. $778 \pm 20 \mu M)$ compared with the HF cattle. The mRNA expression of genes involved in ketogenesis (HMGCS2 and PPARA) and short-chain fatty acid transport (MCT1) was unchanged by treatment. However, a downregulation in HMGCS1 (0.72 \pm 0.09$)$, one of the cholesterol biosynthesis genes, was observed in $\mathrm{HC}$ cattle during wk 1 of the grain challenge. In addition, the relative mRNA expression value of insulinlike growth factor-binding protein 3 was lower $(0.78 \pm$ $0.06)$, whereas insulin-like growth factor-binding protein 5 was higher $(1.79 \pm 0.15)$ in $\mathrm{HC}$ compared with $\mathrm{HF}$ cattle. These results suggest that grain-induced ruminal acidosis alters the mRNA expression of IGFbinding proteins and a cholesterolgenic enzyme in the rumen epithelium of lactating dairy cattle.
\end{abstract}

Received April 18, 2011.

Accepted September 5, 2011.

${ }^{1}$ Corresponding author: bmcbride@uoguelph.ca
Key words: rumen epithelium, ruminal acidosis, gene expression

\section{INTRODUCTION}

Lactating dairy cattle rely on diets rich in rapidly fermentable carbohydrates (high-grain) to increase dietary energy and, thus, production efficiency. When cattle are transitioned abruptly to a high-grain diet, such as during the periparturient period, the rate of short-chain fatty acid (SCFA) production often exceeds the rate of buffering and absorption through the rumen epithelium (RE), making the cow more susceptible to developing the digestive disorder termed ruminal acidosis (Owens et al., 1998). Subacute ruminal acidosis, a common occurrence among commercial dairy operations (Oetzel et al., 1999), is associated with depressed feed intake and production, rumenitis, liver abscesses, and wholeanimal inflammatory response, thereby causing significant economic (Stone, 1999) and animal welfare issues in ruminant production systems (Plaizier et al., 2008).

The rumen adapts to highly fermentable diets by increasing the size of rumen papillae and, thus, the surface area for absorption (Goodlad, 1981; Odongo et al., 2006), yet the molecular signaling mechanisms orchestrating the proliferative changes are still unknown. Among candidate mechanisms, IGF-1 is thought to be involved in RE growth, as it induces RE cell proliferation in vitro (Baldwin, 1999). Cellular events of IGF-1 are modulated by a family of IGF-binding proteins (IGFBP; Firth and Baxter, 2002). In a recent study, the mRNA expression of IGFBP3 and IGFBP6 was downregulated and IGFBP5 was upregulated in the $\mathrm{RE}$ of nonlactating cattle during the transition to a high-grain diet (Steele et al., 2011a). It is unknown if cattle respond in a similar fashion during lactation that is accompanied by increased feed intake (Penner et al., 2011) and altered gastrointestinal function (Cripps and Williams, 1975); therefore, more investigation is necessary.

Although the RE is essential for the absorption of fermentation end products, it also plays an important role in the metabolism of SCFA (Gäbel et al., 2002). It 
has been suggested that ruminal SCFA can be absorbed through passive diffusion and facilitated diffusion via $\mathrm{H}^{+}$-monocarboxylate transporters (Kirat et al., 2006; Graham et al., 2007). Ketogenesis is the main pathway in the RE, as more ketone bodies are synthesized in the RE compared with the liver in the fed state (Leighton et al., 1983). Short-chain fatty acids can be converted to 3-hydroxy-3-methylglutaryl-coenzyme A (HMG-CoA) by HMG-CoA synthase (HMGCS2) in the mitochondria, which proceeds to ketogenesis (Meertens et al., 1998). In the cytoplasm, SCFA can be converted to HMG-CoA by HMGCS1, which proceeds to cholesterol biosynthesis through a series of cytosolic enzymes. To our knowledge, no differences in RE ketogenic gene expression have been detected; however, we recently found that cholesterolgenic genes were downregulated in the $\mathrm{RE}$ of nonlactating cows exposed to a grain challenge (Steele et al., 2011b). It is unknown if the expression signature of cholesterolgenic genes is similar in lactating cattle with higher feed intake, and therefore warrants further exploration.

Despite recent progress in our understanding of how the RE adapts to high-grain diets, the molecular mechanisms remain largely uncharacterized and elusive, especially in the lactating dairy cow. We hypothesized that feeding a high-grain diet to induce ruminal acidosis will alter the expression of genes associated with the IGF axis and cholesterol biosynthesis in the RE of lactating dairy cattle. Therefore, the aims of the current study were to induce a prolonged state of ruminal acidosis in lactating dairy cattle and characterize the mRNA expression of candidate genes involved in $\mathrm{RE}$ metabolism and proliferation.

\section{MATERIALS AND METHODS}

\section{Animals, Experimental Treatments, and Feeding}

Sixteen lactating Holstein dairy cattle $(618 \pm 35 \mathrm{~kg}$ of BW, mean $\pm \mathrm{SD})$ in their second lactation $(221 \pm 32$ DIM, mean \pm SD) were used in a randomized complete block design study. Prior to the start of the experiment, cows were grouped according to stage of lactation into 2 blocks ( $\mathrm{n}=8$ each) and cows within each block were randomly assigned into 1 of 2 dietary treatments. To minimize the effect of stage of lactation on results, each block was enrolled in the experiment when each reached, on average, the above-specified DIM. All experimental procedures were approved by the University of Guelph Animal Care Committee in accordance with the Canadian Council on Animal Care (1993). Cattle were fitted with a rumen fistula during the dry period before their second lactation as described by Duffield (1999), and housed in a tie-stall facility at the Pon- sonby Dairy Research Station (University of Guelph, Guelph, Ontario, Canada). Throughout their lactation, the cattle had unlimited access to fresh water and were milked twice daily in their stalls at 0600 and $1600 \mathrm{~h}$.

Five weeks preceding the experiment, all cattle were gradually transitioned to a high-forage $\operatorname{diet}(\mathbf{H F} ; 88.9 \%$ hay, $6.7 \%$ grain pellet, and $4.4 \%$ supplement, $\%$ of DM; Table 1) over 1 wk. The grain mix comprising $40 \%$ wheat, $40 \%$ barley, and $20 \%$ corn (\% of DM), was fed in equal allotments at 0800,1200 , and $1600 \mathrm{~h}$. The protein supplement and hay were fed at 0800 and 1600 $\mathrm{h}$, also in equal allotments. Throughout the experiment, the concentrate portion was fed in plastic trays and if animals did not consume it within 60 min postfeeding, the remainder was introduced into the rumen through the fistula. Dry matter intake was calculated on a daily basis for each cow throughout the experiment using previously described methodology (Keunen et al., 2002). The average intake for each cow during the baseline week (wk 0) was fed for the remaining 3 wk (wk 1,2, and 3). At the end of wk 0 , the cattle were randomly assigned to the control group (HF diet) or transitioned to a high-concentrate diet (HC; Table 1). Treatment cattle were transitioned to the $\mathrm{HC}$ diet in equal increments over $5 \mathrm{~d}$, which was fed until the end of experimental wk 3 .

\section{DMI, Milk Production, and Milk Components}

All physiological measurements were collected during the final $2 \mathrm{~d}$ of each week (wk 0, 1, 2, and 3). Daily DMI measurements during the final $2 \mathrm{~d}$ of each week were used in the analysis. Milk production was also recorded on a daily basis and milk samples were collected from each milking (0600 and $1600 \mathrm{~h}$ ) for the last $2 \mathrm{~d}$ of each experiment week and analyzed for milk composition at the CanWest DHI Milk Laboratory (Guelph, Ontario, Canada) using infrared spectroscopy (Milkoscan 4000; Foss Electric, Hillerød, Denmark). The yield of milk protein and milk fat produced during the last $2 \mathrm{~d}$ was calculated for each week.

\section{Ruminal pH, Ruminal SCFA, and Plasma BHBA}

Ruminal $\mathrm{pH}$ probes were assembled as described by AlZahal et al. (2007a) and calibrated before weekly recordings. Ruminal $\mathrm{pH}$ was measured every min of the last $48 \mathrm{~h}$ of each experimental week (wk 0, 1, 2, and 3) using a $\mathrm{pH}$ recording system and methodology described previously by our research group (AlZahal et al., 2007b). To characterize how daily ruminal SCFA were altered by treatment, rumen fluid samples were collected at $1600 \mathrm{~h}$ for the last $2 \mathrm{~d}$ of each experimental week. Rumen contents were collected from the ventral 
Table 1. Ingredient composition and chemical analyses of high-forage (HF) and high-concentrate (HC) diets

\begin{tabular}{|c|c|c|}
\hline Composition & $\mathrm{HF}$ & $\mathrm{HC}$ \\
\hline \multicolumn{3}{|c|}{ Ingredient. $\%$ of DM } \\
\hline Supplement ${ }^{1}$ & 4.4 & 4.4 \\
\hline Grain mix & 6.7 & 57.8 \\
\hline Grass hay & 88.9 & 37.8 \\
\hline \multicolumn{3}{|c|}{ Chemical composition, \% of DM } \\
\hline DM, $\%$ & 88.2 & 88.2 \\
\hline $\mathrm{CP}(\mathrm{N} \times 6.25)$ & 16.2 & 14.5 \\
\hline $\mathrm{ADF}$ & 31.8 & 17.6 \\
\hline NDF & 46.9 & 32.3 \\
\hline Lignin & 4.0 & 3.0 \\
\hline Ether extract & 2.2 & 2.5 \\
\hline Ash & 10.6 & 7.1 \\
\hline $\mathrm{NFC}^{2}$ & 27.9 & 46.0 \\
\hline Starch $^{3}$ & 7.4 & 32.1 \\
\hline $\mathrm{NE}_{\mathrm{J}}{ }^{4} \mathrm{Mcal} / \mathrm{kg}$ & 1.4 & 1.7 \\
\hline
\end{tabular}

${ }^{1}$ Contained (\% as-fed basis): dried distillers grains with solubles, 34.6 $48 \%$ soybean meal, 33.4 ; salt, 9.2; monocalcium phosphate, 8.2 ; calcium carbonate (limestone), 5.1; molasses, 4; tallow, Organic Ruminant Micro Premix (Floradale Feed Mill Ltd., Floradale, ON, Canada), 2.8; magnesium oxide, 2.0; sulfur flour (99.5\%), 0.7; and Sel-Plex 2000 (Alltech Inc., Nicholasville, KY), 0.03.

${ }^{2} \mathrm{NFC}=100-(\mathrm{NDF}+\mathrm{CP}+$ ether extract + ash $)$.

${ }^{3}$ Analyzed according to Hall (2000).

${ }^{4}$ Estimated using CPM-Dairy version 3.0.8 (Miner Institute, Chazy, NY) using the chemical analysis of feed ingredients.

sac and squeezed through 3 layers of cheesecloth to recover rumen fluid samples, which were immediately frozen at $-20^{\circ} \mathrm{C}$ until processing. The concentration of SCFA in rumen fluid samples was quantified in duplicate by gas chromatography (Steele et al., 2011a).

To monitor blood BHBA concentration, a 14-gauge catheter (Becton Dickinson Angiocath; Becton, Dickinson and Co., Franklin Lakes, NJ) was inserted into 1 jugular vein of each cow under local anesthesia in the morning before blood collection. Blood samples were collected at $1600 \mathrm{~h}$ during the final $2 \mathrm{~d}$ of each experiment week. Immediately after collection, blood samples were put on ice, centrifuged at $3000 \times g$ for $15 \mathrm{~min}$ and frozen at $-20^{\circ} \mathrm{C}$ until analysis. The concentration of BHBA in plasma was determined in duplicate using an enzymatic kit (kit 310-A; Sigma, Oakville, ON, Canada) following previously described methods (Williamson et al., 1962).

\section{Rumen Papillae Biopsies, RNA Collection, and Quality Assessment}

The ventral sac of the rumen was chosen as a biopsy site because it has the highest capillary blood flow per unit weight mucosa of any location within the rumen (Von Engelhardt and Hales, 1977). Rumen papillae were biopsied from the ruminal ventral sac at the end of wk $0,1,2$, and $3(0700 \mathrm{~h})$ based upon previously developed methodology (Steele et al., 2011b). In brief, the reticulorumen contents were partially evacuated to facilitate the retraction of the ventral sac. Rumen papillae were excised $(150 \mathrm{mg})$ using surgical scissors each week from previously unbiopsied sites, washed 20 times in ice-cold PBS (pH 7.4), snap-frozen in liquid nitrogen, and then stored at $-80^{\circ} \mathrm{C}$ until RNA isolation.

Total RNA was isolated from approximately 100 mg of tissue using an RNeasy midi kit (Qiagen Inc., Mississauga, ON, Canada). The concentration was determined using a NanoDrop spectrophotometer (ND1000; NanoDrop Technologies Inc., Wilmington, DE) and the 260:280 ratio was determined for all samples to be between 1.9 and 2.1. The RNA was then treated with DNase (Invitrogen Canada Inc., Burlington, ON, Canada) before assessing the quality using an Agilent 2100 Bioanalyzer (Agilent Technologies Inc., Palo Alto, CA) and the RNA 6000 Nano kit (Caliper Life Sciences Inc., Mountain View, CA).

\section{Real-Time Reverse-Transcription Quantitative PCR}

To assess mRNA expression of target proliferative and metabolic genes identified from a previous microarray experiment [IGF-binding protein 3 (IGFBP3), IGFbinding protein 5 (IGFBP5), 3-hydroxy-3-methyglutaryl-coenzyme A synthase 1 (HMGCS1), and farnesyl diphosphate synthase $(\boldsymbol{F} \boldsymbol{D P P})$; Steele et al., 2011a,b] and the literature [monocarboxylate transporter 1 (MCT1), peroxisome proliferator-activated receptor alpha (PPARA ), 3-hydroxy-3-methyglutaryl-coenzyme A synthase 1 (HMGCS2), and sterol regulatory element-binding protein 1 and 2 (SREBP1, SERBP2)], quantitative PCR (qPCR) was performed. After RNA isolation and quality assessment, samples (500 ng each) were reverse-transcribed using the high-capacity cDNA reverse transcription kit (Applied Biosystems, Foster City, CA). The Power SYBR Green PCR master mix (Applied Biosystems) was used to perform qPCR in duplicate using an ABI Prism 7000 (Applied Biosystems). The sequences, amplicon size, and primer efficiencies of primers are presented in Table 2. Exon-spanning primers for target genes were designed using Primer Express 3.0 (Applied Biosystems) from bovine sequences listed in GenBank (National Center for Biotechnology Information, Bethesda, MD). The amplicon of all primers designed for this study were sequenced and verified using BLASTN in NCBI (http://www.ncbi.nlm.nih.gov/ blast/Blast.cgi?PAGE $=$ Nucleotides) and dissociation curves were generated at the end of amplification to verify the presence of a single product. The standard curve method with 5 dilutions ranging from 1:5 to 1:3125 was used to calculate the efficiency of qPCR amplification. Based upon previous experimental protocols (Steele et al., 2011b), glyceraldehyde-3-phosphate dehydrogenase 
(GAPDH) was determined to be the most stable housekeeping gene in the rumen papillae and was, therefore, used in this study. For each week, the relative mRNA expression of genes was calculated using the inverse of qPCR efficiency raised to delta cycle threshold (Ct) (Pfaffl, 2001). The HF cattle were pooled for each week to create a control value to which each $\mathrm{HC}$ sample was normalized for determination of relative mRNA expression as described previously (Xue et al., 2010).

\section{Statistical Analysis of Physiological and qPCR Measurements}

Average weekly milk production, ruminal $\mathrm{pH}$ characteristics, ruminal SCFA, and blood BHBA were analyzed using the PROC MIXED of SAS (SAS Institute, 2004) using the following model:

$$
Y_{i j k}=\mu+D_{i}+T_{j}+(D \times T)_{i j}+B_{k}+\varepsilon_{i j k},
$$

where $Y_{i j k}$ is the dependent variable, $\mu$ is the overall mean, $D_{i}$ is the fixed effect of $\operatorname{diet}(i=1,2), T_{j}$ is the fixed effect of time or week $(j=1, \ldots, 4)$, $(D \times T)_{i j}$ is the effect of the interaction of diet by time $(i j=1, \ldots, 8), B_{k}$ is the fixed effect of block or phase $(k=1,2)$, and $\varepsilon_{i j k}$ is the random residual error. Week of experiment was used as a repeated measurement with cow as the subject. For each analyzed variable, cow was subjected to 5 covariance structures: compound symmetry, heterogeneous compound symmetry, autoregressive order 1 , heterogeneous autoregressive order 1 , and unstructured covariance structure. The covariance structure that gave the smallest Bayesian information criterion was used. Because all cows received the HF diet during wk 0 and received either the $\mathrm{HF}$ or the $\mathrm{HC}$ diet during wk 1,2, and 3, the difference between dietary treatments was represented by the interaction between treatment and time. Helmert contrasts compare the mean of each level with the overall mean of the remaining or subsequent levels and were used to evaluate significant changes due to treatment. The first contrast compared wk 0 and average of wk 1, 2, and 3 in the HF group to that in the HC group. The second contrast compared the difference between wk 1 and average of wk 2 and 3 between treatments. The third contrast compared the difference between wk 2 and 3 between treatments. The contrasts were generated using the ESTIMATE statement of SAS. Gene expression values for $\mathrm{HC}$ cattle (generated relative to HF cattle) were analyzed using PROC MIXED of SAS with time (week) and block (phase) as fixed effects. Repeated measurement effect was accounted for as discussed previously. T-statistics were conducted to determine whether $\mathrm{HC}$ relative gene expression values were different from 1 . The associations between relative gene expression values of $\mathrm{HC}$ cattle for specific genes were determined using PROC MIXED of SAS accounting for repeated measurement. An adjusted coefficient of determination was calculated using the GLM of SAS and the model included the adjusted observations as the dependent variables according to St. Pierre (2001).

\section{RESULTS}

\section{DMI, Milk Production, Ruminal $\mathrm{pH}$, Ruminal SCFA, and Plasma BHBA}

All DMI, milk production, ruminal $\mathrm{pH}$, ruminal SCFA, and plasma BHBA results have been summarized in Table 3. No differences were detected in the Helmert contrast between wk 2 and 3 for all variables and were not reported in Table 3. Dry matter intake was decreased $(P<0.01)$ in $\mathrm{HC}$ by $1.7 \pm 0.31 \mathrm{~kg} / \mathrm{d}$ compared with HF cattle. The increased energy density of the diet translated into increased $(P<0.01)$ milk production $(17.4 \pm 0.5$ vs. $23.4 \pm 0.9 \mathrm{~kg} / \mathrm{d})$ and milk protein yield $(559 \pm 16$ vs. $782 \pm 23 \mathrm{~g} / \mathrm{d})$ during all 3 wk. The percentage of milk protein was also higher $(P<0.01)$ throughout the experiment in $\mathrm{HC}$ cattle compared with HF cattle. Milk fat percentage was decreased in HC cattle $(P<0.01)$, but yield of milk fat was not different between treatments (Table 3 ).

Dramatic differences in ruminal $\mathrm{pH}$ were evident between $\mathrm{HC}$ and $\mathrm{HF}$ cattle during experimental wk 1 , 2, and 3 (Figure 1). Week 1 was marked by the largest change in ruminal $\mathrm{pH}(P<0.01)$ as $\mathrm{HC}$ cattle displayed $760 \pm 71 \mathrm{~min} / \mathrm{d}$ and $1,139 \pm 57 \mathrm{~min} / \mathrm{d}$ below 5.6 and 6.0 , respectively. Time below $\mathrm{pH}$ thresholds 5.6 and 6.0 decreased from wk 1 to 2 and $3(P<0.01)$ in $\mathrm{HC}$ cattle, yet was still greater compared with HF cattle $(P<0.01)$. The mean and minimum daily ruminal $\mathrm{pH}$ was lower during every week $(P<0.01)$ in the $\mathrm{HC}$ cattle compared with the HF cattle. The daily minimal ruminal $\mathrm{pH}$ reached levels below $\mathrm{pH} 5.0$ for each experimental week, indicative of a severe state of SARA.

In agreement with ruminal $\mathrm{pH}$ results, total SCFA concentrations were greater $(P<0.01)$ in $\mathrm{HC}$ compared with HF cattle during wk 1, 2, and 3 (Table 3 ). The concentrations of all SCFA were greater in HC cattle throughout the experiment, except for acetate and isobutyrate, which remained unchanged. The ratio of propionate to acetate was lower $(P<0.01)$ in $\mathrm{HC}$ (1.83) compared with HF (2.96) cattle during wk 1, 2, and 3. Of the dominant SCFA (acetate, propionate, and butyrate), ruminal butyrate displayed the largest proportional increase $(P<0.01)$ due to treatment $(6.1$ 
Table 2. Primers for real-time quantitative PCR (qPCR)

\begin{tabular}{|c|c|c|c|c|c|c|}
\hline Gene & Gene name & Gene ID & Primer $^{1}$ & $\begin{array}{l}\text { Amplicon } \\
\text { size }\end{array}$ & Eff $\%^{2}$ & Source \\
\hline$H M G C S 1$ & $\begin{array}{l}\text { 3-Hydroxy-3-methyglutaryl- } \\
\text { coenzyme A synthase } 1\end{array}$ & XM_002696364.1 & F1316-AGAGGATCGGCGTGTTTTCTT & 87 & 93.5 & Steele et al. (2011b) \\
\hline$H M G C S 2$ & $\begin{array}{l}\text { 3-Hydroxy-3-methyglutaryl- } \\
\text { coenzyme A synthase } 2\end{array}$ & NM_001045883 & $\begin{array}{l}\text { R1403-CAGACCCTGGTGTGGCATCT } \\
\text { F1179-TCTGGCCCATCACTCTGCC }\end{array}$ & 126 & 84.0 & Steele et al. (2011b) \\
\hline$F D P S$ & Squalene synthase 1 & NM_177497 & $\begin{array}{l}\text { R1305-AGTGGGGAGCCTGGAGAAGC } \\
\text { F362-GGTATCAGAAGCCAGGCATAGG } \\
\text { R465-TAGGGCTGCTCCCGACAGTA }\end{array}$ & 103 & 93.1 & Steele et al. (2011b) \\
\hline$M C T 1$ & Monocarboxylic acid transporter 1 & NM_001037319.1 & $\begin{array}{l}\text { F137-CGAGCCGCGTATAACGATACTT } \\
\text { R294-GAGAAGCCGATGGAAATGAAAG }\end{array}$ & 157 & 94.5 & \\
\hline$I G F B P 3$ & IGF-binding protein 3 & NM_001075549 & $\begin{array}{l}\text { F855-GCGACAAGAAGGGCTTTTACAA } \\
\text { R936-TATCCACACACCAGCAGAAACC }\end{array}$ & 81 & 85.7 & Steele et al. (2011a) \\
\hline$I G F B P 5$ & IGF-binding protein 5 & NM_001105327 & $\begin{array}{l}\text { F701-CTACAAGAGAAAGCAGTGCAAACC } \\
\text { R764-TCCACGCACCAGCAGATG }\end{array}$ & 63 & 94.6 & Steele et al. (2011a) \\
\hline PPARA & Peroxisome proliferator-activated receptor alpha & NM_001034036.1 & $\begin{array}{l}\text { F342-CGGTGTCCACGCATGTGA } \\
\text { R397-TCAGCCGAATCGTTCTCCTAAA }\end{array}$ & 56 & 91.7 & Loor et al. (2005) \\
\hline$S R E B P 1$ & Sterol regulatory element-binding protein 1 & NM_001113302.1 & $\begin{array}{l}\text { F143-FCCAGCTGACAGCTCCATTGA } \\
\text { R209-TGCGCGCCACAAGGA }\end{array}$ & 67 & 92.5 & Steele et al. (2011b) \\
\hline SREBPथ & Sterol regulatory element-binding protein 2 & XM_002687950.1 & $\begin{array}{l}\text { F147-CTGGCTCCAGGGAGATGAC } \\
\text { R266-GCTCTGCAGGTGTGGAAGAC }\end{array}$ & 120 & 88.0 & Steele et al. (2011b) \\
\hline$G A P D$ & Glyceraldehyde-3-phosphate dehydrogenase & NM_001034034 & $\begin{array}{l}\text { F276-TGGAAAGGCCATCACCATCT } \\
\text { R335-CCCACTTGATGTTGGCAG }\end{array}$ & 60 & 100.3 & Steele et al. (2011b) \\
\hline
\end{tabular}

${ }^{1}$ Exon junctions are underlined.

${ }^{2}$ The PCR efficiency (Eff\%) was calculated as follows: $\mathrm{E}=-1+10^{(-1 / \text { slope })} \times 100$, where $\mathrm{E}=$ efficiency; the slope was obtained by the 5 points standard curve with an $\mathrm{R}^{2}$ of 0.99 . 


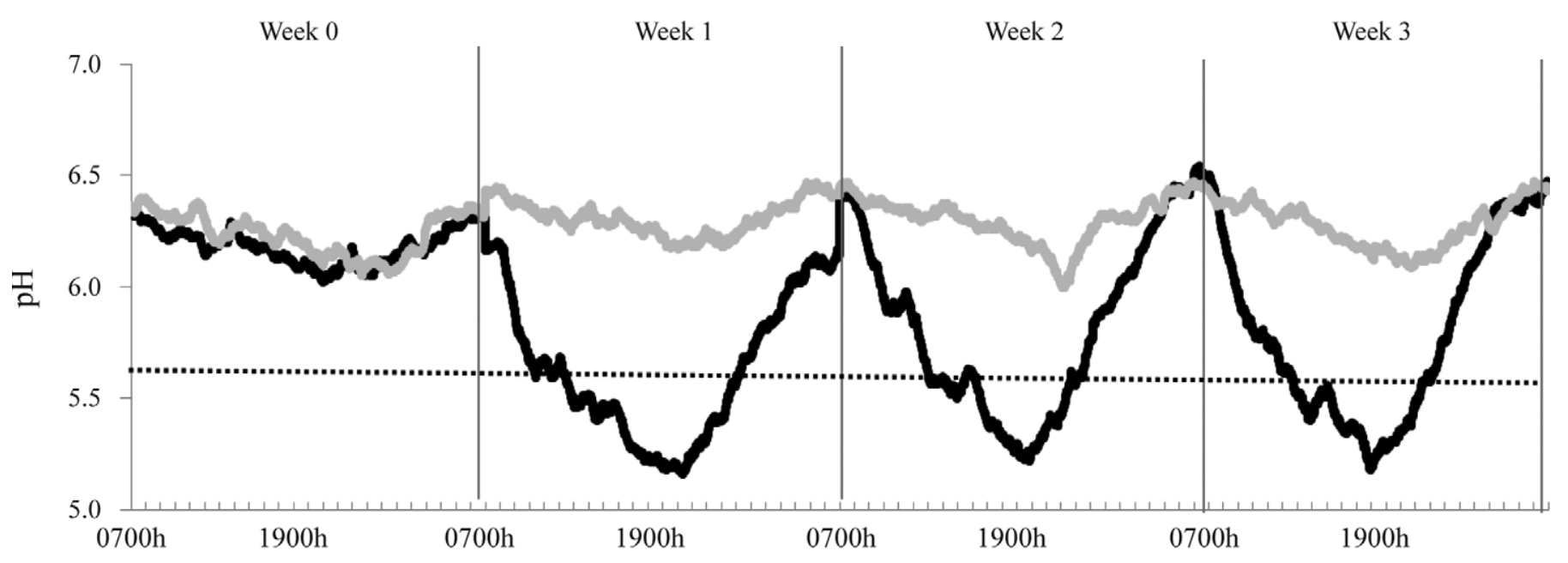

Time of Day

Figure 1. Mean 24-h rumen $\mathrm{pH}$ values for the $2 \mathrm{~d}$ of recordings of cattle fed high-concentrate $(\mathrm{HC}, \mathrm{n}=8$; black $)$ and high-forage $(\mathrm{HF}, \mathrm{n}=$ 8; gray) diets during experimental wk $0,1,2$, and 3. The dashed line represents ruminal $\mathrm{pH}$ threshold 5.6.

$\pm 1.6 \mathrm{mM})$. Plasma BHBA was also higher $(P=0.04)$ in $\mathrm{HC}$ cattle throughout the experiment compared with HF cattle.

\section{Gene Expression}

The relative fold changes between $\mathrm{HC}$ and $\mathrm{HF}$ are presented in Table 4 with the Helmert contrast between wk 0 and the average of wk 1,2 , and 3 . No differences $(P \geq 0.05)$ were detected in the Helmert contrasts between wk 1 and the average of wk 2 and 3 and between wk 2 and 3 for all genes. The mRNA expression was not different between treatments for all genes during the baseline wk 0; however, differential expression was detected in specific genes during wk 1, 2, and 3.

Table 3. The effect of feeding the high-forage (HF) or high-concentrate (HC) diet over time on feed intake, milk production, ruminal pH, ruminal short-chain fatty acids (SCFA), and plasma BHBA ${ }^{1}$

\begin{tabular}{|c|c|c|c|c|c|c|c|c|c|c|c|}
\hline \multirow[b]{2}{*}{ Item } & \multicolumn{4}{|c|}{$\mathrm{HF}$} & \multicolumn{4}{|c|}{$\mathrm{HC}$} & \multirow[b]{2}{*}{$\mathrm{SE}$} & \multicolumn{2}{|c|}{$P$-value ${ }^{2}$} \\
\hline & wk 0 & wk 1 & wk 2 & wk 3 & wk 0 & wk 1 & wk 2 & wk 3 & & 0 vs. 123 & 1 vs. 23 \\
\hline \multicolumn{12}{|l|}{ DMI and production } \\
\hline DMI, kg/d & 19.2 & 19.6 & 19.8 & 20.1 & 19.4 & 18.1 & 18.3 & 18.1 & 0.7 & $<0.00$ & 0.42 \\
\hline Fat, $\%$ & 3.83 & 4.15 & 3.93 & 3.74 & 3.89 & 3.56 & 3.59 & 3.25 & 0.20 & $<0.01$ & 0.40 \\
\hline Fat, kg/d & 0.70 & 0.73 & 0.68 & 0.64 & 0.76 & 0.81 & 0.83 & 0.73 & 0.05 & 0.36 & 0.57 \\
\hline Protein, \% & 3.07 & 3.11 & 3.17 & 3.22 & 2.98 & 3.28 & 3.48 & 3.44 & 0.10 & $<0.00$ & 0.31 \\
\hline Protein, kg/d & 0.56 & 0.54 & 0.55 & 0.56 & 0.59 & 0.75 & 0.81 & 0.78 & 0.03 & $<0.00$ & 0.49 \\
\hline Milk, kg/d & 18.4 & 17.5 & 17.4 & 17.3 & 19.8 & 23.3 & 23.8 & 23.0 & 1.3 & $<0.00$ & 0.90 \\
\hline \multicolumn{12}{|l|}{ Ruminal $\mathrm{pH}$} \\
\hline Mean & 6.24 & 6.31 & 6.30 & 6.29 & 6.18 & 5.63 & 5.81 & 5.82 & 0.06 & $<0.00$ & $<0.01$ \\
\hline Minimum & 5.84 & 5.90 & 5.87 & 5.91 & 5.72 & 5.02 & 5.05 & 5.01 & 0.07 & $<0.00$ & 0.89 \\
\hline Maximum & 6.57 & 6.64 & 6.64 & 6.61 & 6.54 & 6.40 & 6.59 & 6.66 & 0.05 & 0.49 & $<0.01$ \\
\hline$<6.0, \mathrm{~min} / \mathrm{d}$ & 188 & 100 & 121 & 115 & 321 & 1,139 & 885 & 863 & 77 & $<0.00$ & $<0.01$ \\
\hline$<5.8, \mathrm{~min} / \mathrm{d}$ & 54 & 24 & 38 & 17 & 93 & 980 & 665 & 712 & 55 & $<0.00$ & $<0.00$ \\
\hline$<5.6, \mathrm{~min} / \mathrm{d}$ & 6 & 1 & 8 & 0 & 25 & 760 & 468 & 553 & 53 & $<0.00$ & $<0.01$ \\
\hline \multicolumn{12}{|l|}{ Ruminal SCFA, $\mathrm{m} M$} \\
\hline Total & 83.1 & 82.2 & 90.6 & 83.1 & 87.2 & 109.9 & 113.0 & 100.1 & 4.41 & $<0.00$ & 0.22 \\
\hline Acetate & 46.0 & 46.2 & 57.0 & 51.2 & 47.6 & 54.7 & 53.8 & 49.4 & 2.23 & 0.91 & $<0.01$ \\
\hline Propionate & 18.0 & 18.2 & 17.1 & 16.9 & 19.7 & 26.2 & 32.6 & 27.1 & 1.97 & $<0.00$ & 0.11 \\
\hline Butyrate & 11.5 & 10.7 & 10.2 & 9.6 & 12.2 & 18.9 & 17.0 & 14.9 & 1.00 & $<0.00$ & 0.22 \\
\hline Isobutyrate & 3.2 & 2.7 & 2.5 & 2.1 & 3.1 & 3.2 & 3.0 & 3.6 & 0.37 & 0.13 & 0.47 \\
\hline Isovalerate & 1.9 & 1.9 & 1.6 & 1.4 & 2.0 & 3.4 & 2.6 & 2.3 & 0.21 & $<0.01$ & 0.12 \\
\hline Valerate & 2.5 & 2.5 & 2.2 & 1.8 & 2.6 & 3.4 & 3.9 & 2.8 & 0.26 & $<0.01$ & 0.26 \\
\hline Plasma BHBA, $\mu M$ & 665 & 758 & 761 & 796 & 683 & 1,076 & 1,066 & 969 & 79 & 0.04 & 0.52 \\
\hline
\end{tabular}

${ }^{1}$ All cows $(\mathrm{n}=16)$ received HF diet during wk 0 and then were assigned to either the $\mathrm{HC}(\mathrm{n}=8)$ or $\mathrm{HF}(\mathrm{n}=8)$ diet during wk 1,2 , and 3 .

${ }^{2}$ Because all cows received the HF diet during wk 0 , the effect of treatment was best described by the interaction between diet and time. Helmert contrasts were used to describe the interaction between week 0 and weeks 123 and week 1 and weeks 23 . 
Table 4. Least squares means of fold change of the expression of genes in rumen tissue from cattle fed the high-concentrate diet $(\mathrm{HC})$ relative to cattle fed the high-forage diet $(\mathrm{HF})^{1}$

\begin{tabular}{|c|c|c|c|c|c|c|}
\hline \multirow[b]{2}{*}{ Gene $^{2}$} & \multicolumn{4}{|c|}{ Gene expression fold change for $\mathrm{HC}$ relative to $\mathrm{HF}$} & \multirow[b]{2}{*}{$\mathrm{SE}$} & \multirow{2}{*}{$\frac{P \text {-value }}{3}$} \\
\hline & wk 0 & wk 1 & wk 2 & wk 3 & & \\
\hline \multicolumn{7}{|c|}{ IGF signaling } \\
\hline IGFBP3 & 1.08 & $0.67^{*}$ & 0.93 & $0.76^{*}$ & 0.09 & $<0.00$ \\
\hline IGFBP5 & 1.04 & $1.66^{*}$ & $1.90^{*}$ & $1.82^{*}$ & 0.24 & $<0.01$ \\
\hline \multicolumn{7}{|l|}{ Metabolic } \\
\hline$M C T 1$ & 0.95 & 1.23 & 1.03 & 1.06 & 0.19 & 0.37 \\
\hline$P P A R A$ & 0.93 & 1.08 & 1.20 & 0.94 & 0.13 & 0.30 \\
\hline$H M G C S 2$ & 1.01 & 0.99 & 1.09 & 1.01 & 0.20 & 0.93 \\
\hline SREBP 1 & 0.91 & 1.11 & 1.14 & 1.03 & 0.13 & 0.07 \\
\hline SREBP2 & 0.88 & 0.93 & 0.99 & 0.98 & 0.11 & 0.47 \\
\hline$H M G C S 1$ & 0.84 & $0.71 *$ & 0.80 & 0.79 & 0.13 & 0.65 \\
\hline$F D P S$ & 0.87 & 0.93 & 0.85 & 0.88 & 0.09 & 0.83 \\
\hline
\end{tabular}

${ }^{1}$ All cows $(n=16)$ received HF diet during wk 0 and then were assigned to either the HC $(n=8)$ or HF $(n=$ 8) diet. Gene expression values for $\mathrm{HF}$ cattle were normalized to 1 within each week individually.

${ }^{2} I G F B P=$ IGF-binding protein; $M C T 1=$ monocarboxylic acid transporter $1 ; P P A R A=$ peroxisome proliferator-activated receptor alpha; $H M G C S=3$-hydroxy-3-methyglutaryl-coenzyme A synthase; $S R E B P=$ sterol regulatory element-binding protein; FDPS = squalene synthase 1.

${ }^{3}$ Helmert contrasts were used to describe the week effect between week 0 and weeks 123 .

*Weekly means for HC are different $(P<0.05)$ from HF (or 1$)$.

The mRNA expression values of both $I G F B P 3$ and $I G F B P 5$ were responsive $(P<0.01)$ to treatment. In the case of $I G F B P 3$, the mRNA expression was downregulated during wk $1(P<0.01 ; 0.67 \pm 0.09)$ and wk 3 $(P<0.05 ; 0.76 \pm 0.12)$ in the HC cattle compared with the HF cattle. Conversely, IGFBP5 was upregulated in $\mathrm{HC}$ cattle relative to $\mathrm{HF}$ cattle by $1.66 \pm 0.15$ fold $(P<$ $0.05), 1.90 \pm 0.36$ fold $(P<0.01)$, and $1.82 \pm 0.28$ fold $(P<0.01)$ during wk 1,2 , and 3 , respectively.

The Helmert contrasts for metabolic gene expression displayed no differences between $\mathrm{HC}$ and $\mathrm{HF}$ cattle $(P \geq 0.05)$. The HMGCS1 gene was downregulated in HC cattle during wk $1(P=0.02 ; 0.72 \pm 0.09)$ and a trend of downregulation was detected during wk $3(P$ $=0.10 ; 0.79 \pm 0.16)$. Furthermore, the relative mRNA expression values of HMGCS1 and FDPS (cholesterol biosynthesis genes) in $\mathrm{HC}$ cattle were correlated with one another $\left(\mathrm{R}^{2}=0.70 ; P<0.01\right)$.

\section{DISCUSSION}

The goal of this study was to characterize the expression of metabolic and proliferative target genes in the $\mathrm{RE}$ of lactating dairy cattle during the transition from a low- to high-energy diet. To achieve our goal, we established a controlled feeding protocol to minimize variation in DMI, which is a common occurrence in cattle fed rapidly fermentable diets ad libitum (Bevans et al., 2005; Gozho et al., 2005; Penner et al., 2009). The subacute form of ruminal acidosis was detected in every $\mathrm{HC}$ cow during all treatment weeks. Similar to a previous study in nonlactating dairy cattle (Steele et al., 2011a), the lowest ruminal $\mathrm{pH}$ values were recorded during the first week of the grain challenge. The ruminal $\mathrm{pH}$ increased $(P<0.01)$ from wk 1 to 2 ; however, the cattle still remained in a state of SARA. These results are in agreement with previous studies in lactating dairy cattle reporting that ruminal $\mathrm{pH}$ increases during prolonged exposure to a high-grain diet (Matthé et al., 2003; Penner et al., 2007). Despite being in a state of SARA, milk volume and protein production was higher in $\mathrm{HC}$ cattle, a typical production response when the energy density of the diet is increased (Lykos et al., 1997; Keunen et al., 2002).

In accordance with ruminal $\mathrm{pH}$ results, the $\mathrm{HC}$ cattle displayed a significant increase in ruminal SCFA concentration and the ratio of acetate to propionate was decreased, which is in agreement with previous experiments (Harmon et al., 1991; McLeod and Baldwin, 2000). Among measured SCFA, ruminal butyrate in $\mathrm{HC}$ cattle displayed the largest proportional increase in concentration (Table 3), a common observation among several experimental models (Blanch et al., 2009; Penner et al., 2009). This is of particular interest, as ruminal butyrate induces proliferation and epithelial growth in the rumen (Sakata and Tamate, 1978; Mentschel et al., 2001; Gorka et al., 2009) and in the large intestine (Hamer et al., 2008). Therefore, it is possible that the increase in ruminal butyrate during a grain challenge may trigger RE adaptation and growth.

A significant portion of SCFA, especially ruminal butyrate, is metabolized by the RE before entering the portal-drained viscera (Bergman, 1990). It is likely that the dramatic increases in ruminal substrate that occur 
in a state of SARA may influence the flux of key metabolic pathways in the RE. Ketogenesis is a dominant pathway of the RE (Leighton et al., 1983) and the increase in ruminal substrate can be expected to increase RE ketone body synthesis (Lane et al., 2002). In this study, circulating levels of BHBA at $1600 \mathrm{~h}(4 \mathrm{~h}$ after second grain feeding) were higher in $\mathrm{HC}$ cattle relative to HF cattle. Increased concentrations of circulating BHBA have been shown in multiple studies that compare HF and HC diets (Penner et al., 2009; Steele et al., 2009, 2011a,b) and likely reflect a mass action effect of increased substrate for RE ketogenesis.

\section{Gene Expression}

To date, all efforts to elucidate the molecular mechanisms orchestrating $\mathrm{RE}$ adaptation have focused on comparing mRNA expression of nonlactating ruminants fed an HF to those fed an HC diet. Many of the initial studies failed to uncover changes in mRNA expression in the $\mathrm{RE}$ and noted large variability in expression values (Penner et al., 2009). Despite these challenges, several recent studies have successfully identified responsive genes at the mRNA level in nonlactating cattle using microarray technology (Steele et al., 2009, 2011a,b; Taniguchi et al., 2010). Although the expression of mRNA does not necessarily mean that the level of functional protein is expressed in a similar fashion, it is the essential first step when quantifying the molecular response to treatment.

\section{Metabolic Gene Expression}

It has been proposed that, in the case of ketogenic gene expression, largely based on the hepatocyte mod$\mathrm{el}$, the mitochondrial isoform of HMGCS2 controls RE ketogenesis (Hegardt, 1999). The promoter region of HMGCS2 contains a peroxisome proliferator-activated receptor response element and its mRNA expression is thereby controlled by PPARA transcriptional factor (Meertens et al., 1998). In this study, the relative mRNA expression of HMGCS2 and PPARA were not different between the $\mathrm{HF}$ and $\mathrm{HC}$ diets. This is in agreement with previous studies that reported no changes in $\mathrm{RE}$ ketogenic enzyme gene expression despite elevated levels of circulating BHBA (Penner et al., 2009; Steele et al., 2011b). Harmon et al. (1991) found no differences in the production of ketone bodies in rumen papillae slices from cattle fed a $90 \%$ concentrate or $90 \%$ forage diet. These results suggest that the changes in $\mathrm{RE}$ ketogenesis noted above are dependent upon shifts in available substrate with no changes in the expression of ketogenic enzymes. Furthermore, many metabolic genes are diurnally expressed in the gastrointestinal tract of mice (Hoogerwerf et al., 2007); therefore, it is plausible that the same occurs in the RE. Based on the daily change in ruminal $\mathrm{pH}$ in this study (Figure 1; Table 3), it is possible that the expression of ketogenic genes fluctuates during the day.

It has recently been shown that the mRNA expression of genes involved in cholesterol homeostasis is altered in the RE of nonlactating dairy cattle during ruminal acidosis (Steele et al., 2011b). Intercellular hypercholesterolemia can influence a variety of biological processes, such as cellular permeability, proliferation, and inflammation (Kleemann and Kooistra, 2005); therefore, it is tightly regulated (Simons and Ikonen, 2000). Because SCFA are a precursor of cholesterol, the amount of substrate available for RE cholesterol biosynthesis is increased during a grain challenge and the downregulation of these genes may be a means of maintaining intracellular cholesterol homeostasis. In this study, a downregulation of $H M G C S 1$ was detected in $\mathrm{HC}$ compared with $\mathrm{HF}$ cattle only during the first week of the grain challenge when the most severe form of SARA was diagnosed. The expression of HMGCS1 was correlated with FDPS, which are both under the transcriptional control of SREBP2. The inactive form of SREBP2 resides on the endoplasmic reticulum and can translocate to the nucleus after its cleavage (Horton et al., 2002). Because the buildup of cellular cholesterol can block the cleavage of SREBP2 (Hara et al., 1999; Alvaro et al., 2008), it can be hypothesized that the buildup of sterols in the RE may suppress nuclear translocation of SREBP2, thereby downregulating the expression of cholesterol biosynthesis genes.

\section{IGFBP Expression}

It has been well established that increasing dietary energy increases RE proliferation (Goodlad, 1981). Among factors triggering these changes, the luminal increase in SCFA and IGF-1 has received much attention in RE research (Penner et al., 2011). By increasing dietary energy, circulating IGF-1 concentration is increased in the ruminant (Shen et al., 2004), and in cell culture, IGF-1 has been shown to increase RE proliferation (Baldwin, 1999). The IGFBP modulate IGF-1 cellular events in a variety of cell lines (Firth and Baxter, 2002) and have been shown to be related to proliferation in bovine mammary epithelial cells (McGuire et al., 1992).

In this study, we found that IGFBP 5 mRNA expression was increased and IGFBP3 expression was decreased, which is in agreement with our previous findings in nonlactating dairy cattle (Steele et al., 2011a). It has been well characterized that IGFBP3 opposes IGF-1 events (Albiston et al., 1992); therefore, its 
downregulation may encourage cellular growth in the RE. By contrast, IGFBP5 potentiates IGF-1 events; therefore, its upregulation may promote proliferation. In small and large intestinal cell lines it has been shown that SCFA, in particular butyrate, can modulate the expression of IGFBP (Sanderson, 2004). In a transcriptomic study, butyrate induced changes in expression of several IGFBP in kidney epithelial cells ( $\mathrm{Li}$ and $\mathrm{Li}$, 2006). Furthermore, butyrate downregulates the expression of IGFBP3 in intestinal epithelial cells, thereby blocking apoptosis (Sanderson, 2004). This finding is in agreement with Mentschel et al. (2001) who found that ruminal butyrate infusions decreased apoptosis in RE. Therefore, it is feasible that differences in IGFBP expression can influence RE growth independent of the level of IGF-1 in circulation during a grain challenge.

\section{CONCLUSIONS}

Feeding cattle a diet rich in rapidly fermentable carbohydrates increased milk production and milk protein yield in addition to dramatically altering the rumen fermentation profile. The $\mathrm{HC}$ diet caused rumen $\mathrm{pH}$ to decline and ruminal SCFA to increase, especially ruminal butyrate. The relative mRNA expression of $I G F B P 5$ increased, whereas IGFBP3 and HMGCS1 were decreased in the $\mathrm{RE}$ when cattle were fed a diet high in concentrate. The differential expression of these genes offers new insights into the molecular adaptation of the rumen epithelium to high-grain diets. Enhancing our knowledge of the adaptation of the rumen epithelium to high-grain diets may lead to the development of novel technologies or feeding strategies to mitigate the detrimental effects that SARA imposes on ruminant production systems.

\section{ACKNOWLEDGMENTS}

We acknowledge the continued support received from Dairy Farmers of Ontario and the Natural Sciences and Engineering Research Council of Canada (B. W. McBride). We also appreciate the technical help provided by Matthew Walpole, Dave Renaud, Jing Zhang (University of Guelph Genomics Facility), Laura Wright, and the staff at the Ponsonby Dairy Research Station.

\section{REFERENCES}

Albiston, A. L., R. G. Taylor, A. C. Herington, D. J. Beveridge, and P. J. Fuller. 1992. Divergent ileal IGF-I and IGFBP-3 gene expression after small bowel resection: A novel mechanism to amplify IGF action. Mol. Cell. Endocrinol. 83:R17-R20.

Alvaro, A., R. Sola, R. Rosales, J. Ribalta, A. Anguera, L. Masana, and J. C. Vallvé. 2008. Gene expression analysis of a human en- terocyte cell line reveals down regulation of cholesterol biosynthesis in response to short-chain fatty acids. IUBMB Life 60:757-764.

AlZahal, O., E. Kebreab, J. France, and B. W. McBride. 2007a. Mathematical approach to predicting biological values from ruminal $\mathrm{pH}$ measurements. J. Dairy Sci. 90:3777-3785.

AlZahal, O., B. Rustomo, N. E. Odongo, T. F. Duffield, and B. W McBride. 2007b. Technical note: A system for continuous recording of ruminal $\mathrm{pH}$ measurements. J. Anim. Sci. 85:213-217.

Baldwin, R. L. 1999. The proliferative actions of insulin, insulin-like growth factor-I, epidermal growth factor, butyrate and propionate on ruminal epithelial cells in vitro. Small Rumin. Res. 32:261-268.

Bergman, E. N. 1990. Energy contributions of volatile fatty acids from the gastrointestinal tract in various species. Physiol. Rev. 70:567-590.

Bevans, D. W., K. A. Beauchemin, K. S. Schwartzkopf-Genswein, J. J. McKinnon, and T. A. McAllister. 2005. Effect of rapid or gradual grain adaptation on subacute acidosis and feed intake by feedlot cattle. J. Anim. Sci. 83:1116-1132.

Blanch, M., S. Calsamiglia, N. DiLorenzo, A. DiCostanzo, S. Muetzel, and R. J. Wallace. 2009. Physiological changes in rumen fermentation during acidosis induction and its control. J. Anim. Sci. 87:1722-1730.

Canadian Council on Animal Care. 1993. Guide to the Care and Use of Experimental Animals. Canadian Council on Animal Care, Ottawa, ON, Canada.

Cripps, A. W., and V. J. Williams. 1975. The effect of pregnancy and lactation on food intake, gastrointestinal anatomy and the absorptive capacity of the small intestine in the albino rat. Br. J. Nutr. $33: 17-32$.

Duffield, T. F. 1999. A fistful of rumen-a novel approach to rumen fistula surgery. Page 179 in Proc. Am. Assoc. Bovine Pract. 32 Am. Assoc. Bovine Pract., Auburn, AL.

Firth, S. M., and R. C. Baxter. 2002. Cellular actions of the insulinlike growth factor binding proteins. Endocr. Rev. 23:824-854.

Gäbel, G., J. R. Aschenbach, and F. Müller. 2002. Transfer of energy substrates across the ruminal epithelium: Implications and limitations. Anim. Health Res. Rev, 3:15-30.

Goodlad, R. A. 1981. Some effects of diet on the mitotic index and the cell cycle of the ruminal epithelium of sheep. Q. J. Exp. Physiol. 66:487-499.

Gorka, P., Z. M. Kowalski, P. Pietrzak, A. Kotunia, R. Kiljanczyk, J. Flaga, J. J. Holst, P. Guilloteau, and R. Zabielski. 2009. Effect of sodium butyrate supplementation in milk replacer and starter diet on rumen development in calves. J. Physiol. Pharmacol. 60:47-53.

Gozho, G. N., J. C. Plaizier, D. O. Krause, A. D. Kennedy, and K. M. Wittenberg. 2005. Subacute ruminal acidosis induces ruminal lipopolysaccharide endotoxin release and triggers an inflammatory response. J. Dairy Sci. 88:1399-1403.

Graham, C., I. Gatherar, I. Haslam, M. Glanville, and N. L. Simmons. 2007. Expression and localization of monocarboxylate transporters and sodium/proton exchangers in bovine rumen epithelium. Am. J. Physiol. Regul. Integr. Comp. Physiol. 292:R997-R1007.

Hall, M. B. 2000. Starch gelatinization and hydrolysis method. Pages 29-38 in Neutral Detergent Soluble Carbohydrates, Nutritional Relevance and Analysis - A Laboratory Manual. Dept. Animal Science, Univ. Florida, Gainesville.

Hamer, H. M., K. Jonkers, S. Venema, S. Vanhoutvin, F. J. Troost, and R.-J. Brummer. 2008. Review article: The role of butyrate on colonic function. Aliment. Pharmacol. Ther. 27:104-119.

Hara, H., S. Haga, Y. Aoyama, and S. Kiriyama. 1999. Short-chain fatty acids suppress cholesterol synthesis in rat liver and intestine. J. Nutr. 129:942-948.

Harmon, D. L., K. L. Gross, C. R. Krehbiel, K. K. Kreikemeier, M. L. Bauer, and R. A. Britton. 1991. Influence of dietary forage and energy intake on metabolism and acyl-CoA synthetase activity in bovine ruminal epithelial tissue. J. Anim. Sci. 69:4117-4127.

Hegardt, F. G. 1999. Mitochondrial 3-hydroxy-3-methylglutaryl-CoA synthase: A control enzyme in ketogenesis. Biochem. J. 338:569582 . 
Hoogerwerf, W. A., H. L. Hellmich, G. Cornélissen, F. Halberg, V. B. Shahinian, J. Bostwick, T. C. Savidge, and V. M. Cassone. 2007. Clock gene expression in the murine gastrointestinal tract: Endogenous rhythmicity and effects of a feeding regimen. Gastroenterology 133:1250-1260.

Horton, J. D., J. L. Goldstein, and M. S. Brown. 2002. SREBPs: Activators of the complete program of cholesterol and fatty acid synthesis in the liver. J. Clin. Invest. 109:1125-1131.

Keunen, J. E., J. C. Plaizier, L. Kyriazakis, T. F. Duffield, T. M. Widowski, M. I. Lindinger, and B. W. McBride. 2002. Effects of a subacute ruminal acidosis model on the diet selection of dairy cows. J. Dairy Sci. 85:3304-3313.

Kirat, D., J. Masuoka, H. Hayashi, H. Iwano, H. Yokota, H. Taniyama, and S. Kato. 2006. Monocarboxylate transporter1 (MCT1) plays a direct role in short-chain fatty acids absorption in caprine rumen. J. Physiol. 576:635-647.

Kleemann, R., and T. Kooistra. 2005. HMG-CoA reductase inhibitors: Effects on chronic subacute inflammation and onset of atherosclerosis induced by dietary cholesterol. Curr. Drug Targets Cardiovasc. Haematol. Disord. 5:441-453.

Lane, M. A., R. L. Baldwin VI, and B. W. Jesse. 2002. Developmental changes in ketogenic enzyme gene expression during sheep rumen development. J. Anim. Sci. 80:1538-1544.

Leighton, B., A. R. Nicholas, and C. I. Pogson. 1983. The pathway of ketogenesis in rumen epithelium of the sheep. Biochem. J. 216:769-772.

Li, R. W., and C. J. Li. 2006. Butyrate induces profound changes in gene expression related to multiple signal pathways in bovine kidney epithelial cells. BMC Genomics 7:234.

Loor, J. J., H. M. Dann, R. E. Everts, R. Oliveira, C. A. Green, N. A. Guretzky, S. L. Rodriguez-Zas, H. A. Lewin, and J. K. Drackley. 2005. Temporal gene expression profiling of liver from periparturient dairy cows reveals complex adaptive mechanisms in hepatic function. Physiol. Genomics 23:217-226.

Lykos, T., G. A. Varga, and D. Casper. 1997. Varying degradation rates of total nonstructural carbohydrates: Effects on ruminal fermentation, blood metabolites, and milk production and composition in high producing Holstein cows. J. Dairy Sci. 80:3341-3355.

Matthé, A., P. Lebzien, I. Hric, and G. Flachowsky. 2003. Influence of prolonged adaptation periods on starch degradation in the digestive tract of dairy cows. Anim. Feed Sci. Technol. 103:15-27.

McGuire, M. A., J. L. Vicini, D. E. Bauman, and J. J. Veenhuizen. 1992. Insulin-like growth factors and binding proteins in ruminants and their nutritional regulation. J. Anim. Sci. 70:2901-2910.

McLeod, K. R., and R. L. Baldwin. 2000. Effect of diet forage:concentrate ratio and metabolizable energy intake on visceral organ growth and in vitro oxidative capacity of gut tissues in sheep. J. Anim. Sci. $78: 760-770$

Meertens, L. M., K. S. Miyata, J. D. Cechetto, R. A. Rachubinski, and J. P. Capone. 1998. A mitochondrial ketogenic enzyme regulates its gene expression by association with the nuclear hormone receptor PPAR $\alpha$. EMBO J. 17:6972-6978.

Mentschel, J., R. Leiser, C. Mulling, C. Pfarrer, and R. Claus. 2001. Butyric acid stimulates rumen mucosa development in the calf mainly by a reduction of apoptosis. Arch. Tierernähr. 55:85-102.

Odongo, N. E., O. AlZahal, M. I. Lindinger, T. F. Duffield, E. V. Valdes, S. P. Terrell, and B. W. McBride. 2006. Effects of mild heat stress and grain challenge on acid-base balance and rumen tissue histology in lambs. J. Anim. Sci. 84:447-455.

Oetzel, G. R., K. V. Nordlund, and E. F. Garrett. 1999. Effect of ruminal $\mathrm{pH}$ and stage of lactation on ruminal lactate concentrations in dairy cows. J. Dairy Sci. 82(Suppl. 1):38 (Abstr.)

Owens, F. N., D. S. Secrist, W. J. Hill, and D. R. Gill. 1998. Acidosis in cattle: A review. J. Anim. Sci. 76:275-286.

Penner, G. B., K. A. Beauchemin, and T. Mutsvangwa. 2007. Severity of ruminal acidosis in primiparous Holstein cows during periparturient period. J. Dairy Sci. 90:365-375.
Penner, G. B., M. A. Steele, J. R. Aschenbach, and B. W. McBride. 2011. Molecular adaptation of ruminal epithelia to highly fermentable diets. J. Anim. Sci. 89:1108-1119.

Penner, G. B., M. Taniguchi, L. L. Guan, K. A. Beauchemin, and M. Oba. 2009. Effect of dietary forage to concentrate ratio on volatile fatty acid absorption and the expression of genes related to volatile fatty acid absorption and metabolism in ruminal tissue. J. Dairy Sci. 92:2767-2781.

Pfaffl, M. W. 2001. A new mathematical model for relative quantification in real-time RT-PCR. Nucleic Acids Res. 29:2002-2007.

Plaizier, J. C., D. O. Krause, G. N. Gozho, and B. W. McBride. 2008. Subacute ruminal acidosis in dairy cows: The physiological causes, incidence and consequences. Vet. J. 176:21-31.

Sakata, T., and H. Tamate. 1978. Rumen epithelial cell proliferation accelerated by rapid increase in intraruminal butyrate. J. Dairy Sci. 61:1109-1113.

Sanderson, I. R. 2004. Short chain fatty acid regulation of signaling genes expressed by the intestinal epithelium. J. Nutr. 134:2450S$2454 \mathrm{~S}$.

SAS Institute. 2004. SAS/STAT User's Guide. Release 9.1. SAS Inst. Inc., Cary, NC.

Shen, Z., H.-M. Seyfert, B. Löhrke, F. Schneider, R. Zitnan, A. Chudy, S. Kuhla, H. A. Hammon, J. W. Blum, H. Martens, H. Hagemeister, and J. Voigt. 2004. An energy-rich diet causes rumen papillae proliferation associated with more IGF type 1 receptors and increased plasma IGF-1 concentrations in young goats. J. Nutr. 134:11-17.

Simons, K., and E. Ikonen. 2000. How cells handle cholesterol. Science 290:1721-1726

St-Pierre, N. R. 2001. Invited review: Integrating quantitative findings from multiple studies using mixed model methodology. J. Dairy Sci. 84:741-755.

Steele, M. A., O. AlZahal, S. E. Hook, J. Croom, and B. W. McBride. 2009. Ruminal acidosis and the rapid onset of ruminal parakeratosis in a mature dairy cow: A case report. Acta Vet. Scand. 51:39.

Steele, M. A., J. Croom, M. Kahler, O. AlZahal, S. E. Hook, K. Plaizier, and B. W. McBride. 2011a. Bovine rumen epithelium undergoes dramatic structural adaptations during grain-induced ruminal acidosis epithelial adaptation. Am. J. Physiol. Integr. Comp. Phys. 300:R1515-R1523.

Steele, M. A., G. Vandervoort, O. AlZahal, S. E. Hook, J. C. Matthews, and B. W. McBride. 2011b. Rumen epithelial adaptation to high-grain diets involves the coordinated regulation of genes involved in cholesterol homeostasis. Physiol. Genomics 43:308-316.

Stone, W. C. 1999. The effect of subclinical rumen acidosis on milk components. Pages 40-46 in Proc. Cornell Nutr. Conf. Department of Animal Science, Cornell University, Ithaca, NY.

Taniguchi, M., G. B. Penner, K. A. Beauchemin, M. Oba, and L. L. Guan. 2010. Comparative analysis of gene expression profiles in ruminal tissue from Holstein dairy cows fed high or low concentrate diets. Comp. Biochem. Physiol. D Genomics Proteomics 5:274-279. doi:10.1016/J.cbd.2010.07.004.

Von Engelhardt, W., and J. R. S. Hales. 1977. Partition of capillary blood flow in rumen, reticulum, and omasum of sheep. Am. J. Physiol. 232:E53.

Williamson, D. H., J. Mellanby, and H. A. Krebs. 1962. Enzymatic determination of $\mathrm{d}(-)-\beta$-hydroxybutyric acid and acetoacetic acid in blood. Biochem. J. 82:90-96.

Xue, Y., S. F. Liao, K. W. Son, S. L. Greenwood, B. W. McBride, J. A. Boling, and J. C. Matthews. 2010. Metabolic acidosis in sheep alters expression of renal and skeletal muscle amino acid enzymes and transporters. J. Anim. Sci. 88:707-717. 